\title{
Research on the Competitiveness of Human Resources in China from the Perspective of International Comparison
}

\author{
Liu Junyong \\ Weinan Normal University, Weinan, Shaanxi, 714000
}

Keywords: International Comparative Perspective, China, Human Resources, Competitiveness, Research

\begin{abstract}
Talent is the core of the development of a country and enterprise, so the most important thing in today's society is the talent. With the development of the economy and the progress of the society, talent has become an indispensable part of today's society. The level of talents in a country or a region determines the level of economic and technological development of a country to a large extent. We can say that the competition in today's society is the competition of talents. More and more countries pay more and more attention to the development of talents. China attaches great importance to the development of talents and attaches great importance to the practice of human resources management. The traditional management mode is no longer suitable for the current national conditions and economic development. China is actively introducing the advanced human resource management mode, giving full play to the role of talents, improving the competitiveness of human resources.
\end{abstract}

\section{Introduction}

With the development of globalization, exchanges between countries and regions are increasing, and full exchange has made the competition between countries increasing. In the competition and comparison, countries have virtually improved their strength and international competitiveness. Therefore, in continuous communication and competition, cultural soft power and talent competition become a new form of international competition [1]. It can be said that the competition of talents in today's world is the competition of international comprehensive strength. The level of national talent competitiveness determines the overall strength of the country. Therefore, we should pay more attention to the cultivation of talent and innovative talent management model, fully tap the talents, and the talents of our country and reasonable management, to maximize the value of talent, enhance the competitiveness of Chinas talent, improve the comprehensive strength of our country, to realize the great dream of China.

\section{Analysis of the Strategic Theory of Human Resources Competitiveness under the International Comparison}

The competitiveness of human resources mainly includes the human resource competitiveness among countries, the competitiveness of human resources among enterprises and the individual human resources competitiveness of workers. This is divided according to micro perspectives and is respectively expressed as the sum of labor resources in a country, the total amount of labor resources in an enterprise organization that can generate value for the enterprise, and the individual's personal experience through education, physical strength and technology have a certain value to society or business [2-3].

Through the analysis of the process of modern society, we can see that the overall level of human resource directly or indirectly influences the economic development and comprehensive strength of the country. In the case of the national hard strength, the countries and regions with higher human resources level must be stronger in comprehensive national strength. Therefore, if a country can't keep up with the hard power or the system is not sound, it can promote the overall development and progress of the country by developing the level of human resources. 
China is a socialist developing country with a large population, and its advantages are rich human resources. How to transform a large number of population advantages into talent advantage is the development goal of our past, present and even future [4]. The strategy of "invigorating the country by science and education and developing a country with great power" is a sign that China has stepped into a solid step from a large population to a powerful country. China's resumption of the college entrance examination system, the popularization of nine years compulsory education and the appearance of private schools are all aimed at encouraging and developing education and cultivating new and modern talents. According to statistics, the coefficient of chasing human resources in the United States in 1905 was only 11.9\%. After 60 years of development, the catch up coefficient has reached $73.8 \%$ in 2010 [5]. This shows that China has achieved great success in transforming from a large population country to a powerful country of human resources. At the same time, we must adhere to the goal of building a moderately prosperous society in an all round way, realize the common prosperity of the whole society, realize educational equity and solve the worries of the people, so as to develop the talent advantage.

\section{Research on the Present Situation of Human Resources Competitiveness between China and Abroad under the International Comparison}

\subsection{Research on the status of human resources competitiveness of foreign advanced countries from the perspective of international comparison}

First of all, we study the current situation of the competitiveness of human resources in the United States. The United States is not only the most developed country in the world, but also its education and management ideas are more advanced. The United States is the first batch of countries to realize the capitalist system, so it has a long history and advanced management experience in human resource management. The human resource strategy of the United States is supported by the state [6-7]. It relies on the visible hand of the state to make macro adjustments and controls, and determines the direction of human resources policy according to the market economy. The United States not only attaches importance to the basic education of talents, but also focuses on the practical ability of talents. It attaches importance to training the comprehensive ability of talents and realizing the goal of developing all-round talents.

After taking the defeat of the world wars in the 1970s and 1980s, Japan learned from its experience and lessons and actively developed the country's overall strength and developed itself into a developed country. The implementation of human resources competitiveness strategy in Japan is mainly based on the core of human centered and labor capital coordination. The humanized management mechanism is a major feature of human resource management in Japan. Japan mainly regulates the flow of talent through the market economy, and advocates unseen hands to regulate the market economy and the flow of talent resources [8]. But at the same time, Japan adhered to the fixed talents, avoiding frequent turnover of talents, resulting in temporary vacancies, which had an impact on product quality and production line, and ensured the stability of product quality and professionalism of talent resources.

\subsection{Research on the current situation of human resources competitiveness in China under the international comparison}

China is a socialist developing country with a large population, and its advantages are rich human resources. In the past due to economic backwardness, restrict people's right to education, the low quality of the population; patriarchal ideology, also makes the female education thought is suppressed, the human resources development in China is not optimistic. But from the founding of new China and the implementation of the policy of reform and opening to the outside world, the strategy of "invigorating the country through science and education and strengthening our talents" has marked a solid step in the direction of China from a large population to a powerful country [9]. China's resumption of the college entrance examination system, the popularization of nine years compulsory education and the appearance of private schools are all aimed at encouraging and 
developing education and cultivating new and modern talents. After the implementation of China's education in the last few decades, the average education level of the population in China has been greatly improved. The economic development of our population is shifting from the first industry and the second industry to the third industry, marking the progress of our economic structure and the progress of human resources.

\section{The Main Reasons for the Shortage of Human Resources in China at Present}

At present, the main reasons for the lack of competitiveness of human resources in China are: first, the state started late and experienced the great leap forward, which is a severe blow to China's economic development. The persecution of the outstanding talents of the state has caused great loss in our country, which makes our country need great effort and long time to recover and develop in the later period. Two, China has a large population base and large population. However, the limited level of education and development has limited the rights of education in most rural and poverty-stricken areas [10]. There has been a nationwide imbalance in the development of education, resulting in unbalance of population development and unrest in some areas. Three, as China's human resources development strategy is still in the primary stage, it is relative to the developed country's talent development strategy. The policies and measures in all aspects of our country are not very perfect, and the right to equal education and the protection of professional fairness in the population still need to be improved.

\section{Countermeasures to Improve the Competitiveness of Human Resources in China from the Perspective of International Comparison}

\subsection{People from all walks of life should attach great importance to the development of human resources}

\subsubsection{Countries should attach importance to the development of human resources in China}

The state should pay more attention to the training of all - type and professional talents, increase the investment of financial funds and guarantee the input of basic education. We should strengthen the professional innovation ability of the talents, reform the education and examination rules, and ensure that every Chinese people have the right to fair education [11].

\subsubsection{Enterprises attach importance to talent training}

The enterprise should pay attention to the training of staff, for the traditional old employees to conduct regular training, improve their level of computer operation, achieve the level of computer and business ability at the same time; through the development of relevant incentive mechanism and incentive system, further encourage unit personnel, through the process to obtain various qualifications to gain knowledge learning and practice ability.

\subsubsection{Schools attach importance to education}

Schools are the most important part of the entire human resource chain. Therefore, schools should formulate and modify various teaching plans according to the development needs of current educational policies, and train high-quality talents to meet the needs of industry development.

\subsubsection{Talents improve their own quality}

We should also work hard to learn scientific and cultural knowledge, establish good personal morality and professional ethics, and strengthen our own constraints. At the same time, we must keep pace with the times, improve our professional quality and professional ability, and constantly adapt to the needs of economic development and industry development, and make all-around professional talents. 


\subsection{Improve the management model of human resources in Enterprises}

Improving the management model of human resources is also one of the ways to improve the competition of human resources in China. First of all, the establishment of reward and punishment mechanism is an essential part of enterprise human resource management. Through the survival of the fittest, excellent employees should give good promotion space. Secondly, the staffs who do not meet the needs of the post should strengthen the training to adapt to the basic needs of the post [12]. For employees who are totally not suited to their positions, they should give humane care, timely adjust staff positions, achieve staff value, and achieve rational allocation of human resources within enterprises, so as to reduce the actual business cost of enterprises. Through training assessment, enterprises can comprehensively assess employees with high professional quality, improve the space and opportunities for excellent employees, help outstanding talents to be discovered and inspire their fighting spirit and motivation. Through the promotion mechanism, the reasonable arrangement of posts is guaranteed, and the rational allocation of talent resources is ensured. Finally, the reward of promotion and salary can stimulate the working motivation of the employees and invigorate the good atmosphere of the enterprise. Through the incentive and publicity of the enterprise, the personal value of the employee is reflected, and it can also retain the talents, which is of great significance to the cultivation of human resources.

\subsection{Increase investment in human resources management in China}

In the past, the capital was mainly used in industrial production because of the lack of funds in the country, and the investment in education was relatively small. Nowadays, China has developed rapidly and has become the second largest economy in the world. It has already been able to meet the expenditure in the field of talent construction. Therefore, the state should increase investment in financial funds, support the innovation of high and new technology enterprises and train professionals in the network, and establish a sound funding system to ensure that talent education has enough financial support. At the same time, as the backbone of national talent training, enterprises should fully recognize their social responsibilities, recognize the importance of national personnel training, and assume the responsibilities and obligations to cultivate social talents. Enterprises can absorb a large number of young and energetic talents to promote the development of enterprises. At the same time, enterprises should actively respond to the national reform of talent cultivation mode, develop the economy, and provide more practical jobs for the development of schools and students. The school should also pay attention to the training of talents, let this idea infiltrate into the classroom team and play the role of teachers as the main force of talent training. To reform the teaching staff, teachers should have excellent selection, select high-quality teachers, keep pace with the reform of educational system, and play a major role in talent education.

\section{Conclusion}

All in all, though there is a certain gap between China and foreign human resources competitiveness, this does not mean that we should accept passively or even deal with it negatively. It is not a smooth sailing to realize the substantial leap in the competitiveness of the national human resources. The whole process is long and complicated. We should have a comprehensive vision and rigorous analysis. We should make full and reasonable judgement for the actual situation of different problems in every stage of the economic market. According to the specific circumstances of the state and enterprises, different human resource management plans are set up. Only by achieving the effectiveness of the phased human resource management at each stage can we achieve the competitiveness of human resources in the whole development process of the country.

\section{References}

[1] Zhu X J. Analysis on the Competitiveness of Human Resources in the Market from the Perspective of Internationalization[J]. Journal of Hubei Correspondence University, 2016. 
[2] Sun W, Du X. On human resource management of Chinese colleges: From the perspective of knowledge management[C]// International Conference on Information Management, Innovation Management and Industrial Engineering. IEEE, 2013:436-439.

[3] Cui Y M, Zeng L F, Chen Z A. Research on the Effect and Channels of the Education Dividend on the International Competitiveness of China's Manufacturing Industry[J]. Journal of International Trade, 2016.

[4] Li R. A Comparative Study on the Competitiveness of Major Ports Between China and Singapore in the Perspective of International Trade[J]. Reformation \& Strategy, 2016.

[5] Lou X, Wang Y. Evaluation Index for Strong Human Resource Provinces Established_—Based on the Competitive Perspective of Regional Human Resources[J]. China Labor, 2015.

[6] Zhou Y, Yong-An L I. International Comparison of Trade Competitiveness of China's Railway Equipment Products__An Analysis based on State “Diamond” Model[J]. Prices Monthly, 2016.

[7] Cong H B, Zou D L, Economics S O, et al. The Comparative Analysis of the International Competitiveness of Creative Goods Trade in China and Japan-Based on the Perspective of the International Division of Labor[J]. Future \& Development, 2014.

[8] Pansuwong W. Evaluating competitiveness of the convention destination: a primary stakeholders' perspective in Chiang Mai City, Thailand[J]. International Journal of Services Economics \& Management, 2017, 8(1/2):1.

[9] Qiu X L, Jian-Hui Y U. An Analysis of International Competitiveness of China's Papermaking Industry from the Perspective of Low-carbon Economy[J]. Journal of Anhui Agricultural University, 2014.

[10] Zhou Y, Wang Z. A Study on Food Safety Supervision System in China: Based on the Perspective of International Comparison[J]. Journal of Macro-Quality Research, 2014.

[11] Liu X, Cai L, Tan H. Analysis of Enhancing the Competitiveness of China Machine Tool Industry from the Perspective of Foreign Trade[J]. Advances in Management \& Applied Economics, 2013, 3(1).

[12] Zhang W. The Comparison of Chinese and Vietnamese Evidence for Sovereignty over the Nansha Islands__From the Perspective of Dispute Settlement of the International Court of Justice[J]. Pacific Journal, 2014. 